\title{
SUMMARY
}

PHYSICO-CHEMICAL, STIMULATION AND DEVELOPMEN'T OF THE RUMEN

A previous paper concluded in favour of a chemical stimulation of the development of the mucous membrane in the rumen and of a mechanical effect of the friction of coarse particles in the ration on the development of the muscle layer of the rumen wall in the young calf.

We related this physico-chemical stimulation of the anatomical development of the organ to the changes in its histological structure and absorptive ability.

Owing to the effect of a chemical stimulation (slow intraruminal infusion of volatile fatty acids or of ammonia solution) the histological structure of the mucous membrane in young calves develops like that resulting from consumption of solid feed. The large development of papillary bodies is the most striking factor. The sole presence of inert bulk in the rumen (plastic particles) induces an histological structure comparable with that of milk-fed calves : no papillary bodies, ill-defined cellular layers.

The ability of the rumen to absorb large quantities of volatile fatty acids or ammonia is not inherent in the immature rumen. The stimuli required for increasing the absorptive ability are the same as those of the histo-anatomical development of the mucous membrane in the rumen. Development of the absorptive ability seems, according to the metabolites to be absorbed, to depend either on the structural maturation of the mucous membrane when absorption is passive (acetic and propionic acids) or on the appearance of specific transport systems when it is accompanied by a metabolism through the ruminal mucosa (ammonia), or on both factors (butyric acid).

These results show that the active metabolism of the nutrients absorbed within the rumen epithelium is one of the most determining factors of the histo-anatomical development of the mucous membrane and of its absorptive ability. On the other hand, the development of the muscle layer depends on the mechanical stimulation of the reflex zones of the rumen motility.

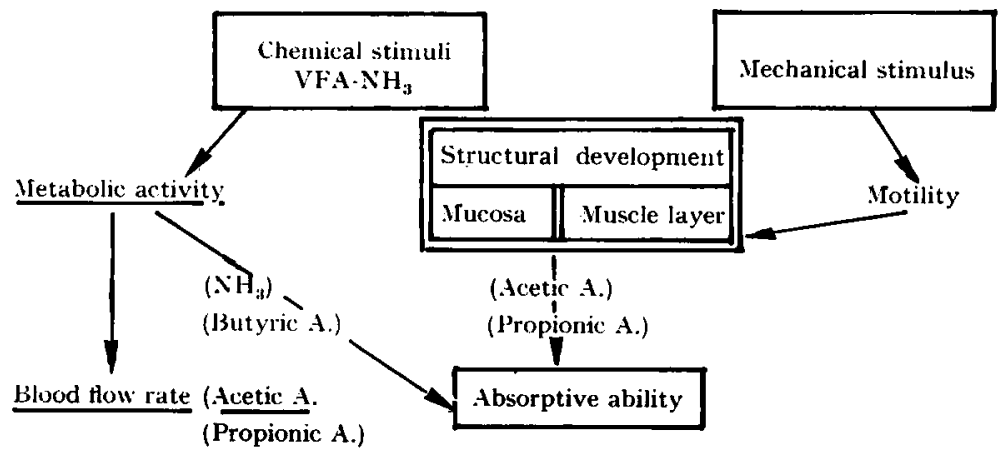

FIG. 1. - Physico-chenical stimulation and development of the rumen

\section{ÉTUDE « IN VITRO » DE LA PROTÉOLYSE ET DE LA PROTÉOSYNTHÈSE DANS LE RUMEN}

\author{
R. VÉRITÉ et M. JOURNET
}

Station de Recherches sur l'élevage des Ruminants, Centre de Recherches de Clermont-Ferrand, I. N. R. A., Theix, 63110 Beaumont

La quantité d'acides aminés disponible au niveau de l'intestin du ruminant est fonction de la quantité de protéines alimentaires qui échappent à la dégradation en ammoniaque (protéolyse) 
dans le rumen et de la quantité de protéines microbiennes synthétisées (protéosynthèse) à partir de l'ammoniaque. Par une technique simple d'incubation de contenus de rumen nous avons essayé de mesurer l'importance de la protéolyse et de la protéosynthèse et de leurs variations à partir de l'évolution de la teneur en ammoniaque du milieu.

La technique utilisée consiste à faire incuber dans un Erlenmeyer (pendant $6 \mathrm{~h}$ ) la source azotée (environ $0,25 \mathrm{~g}$ d'azote) avec de fortes quantités de contenus de rumen (200 g) et de jus $(200 \mathrm{ml})$ prélevés I heure après le repas, $400 \mathrm{ml}$ de salive artificielle de McDougall et une source d'énergie ( 3 à Io $\mathrm{g}$ d'orge ou de pulpe selon les essais). Le contenu et le jus de rumen proviennent de vaches fistulisées habituées à ingérer la ration et la source azotée testées.

\section{A. - Protéolyse comparée de différentes sources protéiques}

Une protéolyse (ou ammoniogenèse) importante est caractérisée par une concentration élevée en ammoniaque au début de la fermentation (après $\mathrm{I} h$ ) et par une diminution faible ou même un accroissement de cette concentration ensuite. Ces 2 critères nous ont permis de classer les sources azotées étudiées par ordre décroissant d'importance de la protéolyse (quelle que soit la ration utilisée) : tourteau d'arachide, tourteau de soja, luzerne déshydratée. La proportion d'azote des tourteaux transformée en ammoniaque a été calculée par 2 méthodes : $I^{\circ}$ en ajoutant l'ammoniaque utilisé pour la protéosynthèse à l'ammoniaque apparamment formé au cours de l'incubation (pour une ration donnée on a supposé que la protéosynthèse obtenue avec les tourteaux était la même que celle obtenue avec l'urée ; $2^{\circ}$ en comparant la cinétique des teneurs en ammoniaque obtenue avec les sources azotées étudiées à celles obtenues avec une incubation témoin sans source azotée supplémentaire. La proportion d'azote des tourteaux transformée en ammoniaque au cours de l'incubation a été respectivement pour les tourteaux de soja et d'arachide de $2 \mathrm{I}, 2 \pm \mathrm{I}, 6$ et $4 \mathrm{I}, 3 \pm 2,9$ p. Ioo par la première méthode et de II,9 $\pm \mathrm{I}, 4$ et $32,0 \pm 2,8$ p. Ioo par la deuxième méthode.

\section{B. - Protéosynthèse à partir de l' $N$ de l'urée}

L'hydrolyse de l'urée étant immédiate (le maximum de concentration en ammoniaque est observé $\mathrm{I} / 2$ heure après le début de l'incubation), la protéosynthèse peut être mesurée par la quantité d'azote ammoniacal disparue au cours de l'incubation.

L'importance de la protéosynthèse a été fonction de la ration utilisée (rations isoénergétiques). Les rations se sont classées dans l'ordre décroissant suivant : $1^{\circ}$ ensilage de maïs, $2^{\circ}$ foin de graminées + pulpes, $3^{\circ}$ foin de graminées + betteraves (Essai I, tabl. I). La diminution de la protéosynthèse a correspondu à une diminution des fermentations (quantité de gaz et d'acides gras volatils produits) ainsi qu'à une diminution de la quantité d'azote microbien formé rapportée à celle d'acides gras volatils.

Avec tous les régimes étudiés la luzerne déshydratée ajoutée au milieu de fermentation a eu un effet stimulant sur la protéosynthèse (tabl. I).

Cette méthode nécessite d'être améliorée en particulier pour mieux tenir compte de l'ammoniogenèse à partir des contenus eux-mêmes mais nous paraît un moyen d'analyse intéressant des différents facteurs qui peuvent influer sur la protéolyse et la protéosynthèse. Les quantités d'azote microbien synthétisées par moles d'AGV (o,8 à $3 \mathrm{~g})$ ont été inférieures en moyenne aux valeurs observées $(2,4$ à $2,8 \mathrm{~g})$ in vitro $\left(\mathrm{S}^{35}\right)$ par WALKER et NADER (1968) et in vivo par Hogan et WESTON (1970).

\section{RÉFÉRENCES BIBLIOGRAPHIQUES}

Hogan J.-P., Weston R. H., I970. Physiology of digestion and metabolism in the ruminant by A. T. Phillipson, p. 474-485.

Walker D. J., Nader C. J., I968. Appl. Microbiol., 16, II24. 
TABLEAU I

Protéosynthèse à partir de l'azote de l'urée:

Quantité d'azote ammoniacal disparue au cours de l'incubation $(6 \mathrm{~h})$

Proteosynthesis from $N$ urea

Quantity of ammoniacal nitrogen disappeared during incubation $(6 \mathrm{~h})$

\begin{tabular}{|c|c|c|c|c|c|c|c|c|c|}
\hline \multirow{2}{*}{ Essai } & \multirow{2}{*}{ Régime } & \multicolumn{2}{|c|}{$\mathrm{mg} \mathrm{N}$} & \multicolumn{2}{|c|}{$\mathrm{mg} \mathrm{N} / \mathrm{l}$ de gaz } & \multicolumn{2}{|c|}{$\mathrm{mg} \mathrm{N} / \mathrm{m} \mathrm{d}^{\prime} \mathrm{AGV}$} & \multirow{2}{*}{ Diet } & \multirow{2}{*}{ Assay } \\
\hline & & 1 & 2 & 1 & 2 & 1 & 2 & & \\
\hline I & $\begin{array}{l}\text { Ensilage de mais } \\
\text { Foin }+ \text { pulpes } \\
\text { Foin }+ \text { betteraves }\end{array}$ & $\begin{array}{l}82 \\
49 \\
29\end{array}$ & $\begin{array}{r}131 \\
86 \\
70\end{array}$ & $\begin{array}{l}34 \\
26 \\
17\end{array}$ & $\begin{array}{l}49 \\
36 \\
33\end{array}$ & $\begin{array}{l}\mathbf{1 , 5 8} \\
\mathbf{1 , 1 8} \\
0,79\end{array}$ & $\begin{array}{l}2,35 \\
1,73 \\
1,55^{*}\end{array}$ & $\begin{array}{l}\text { Maize silage } \\
\text { Hay }+ \text { pulps } \\
\text { Hay }+ \text { beets }\end{array}$ & $I$ \\
\hline II & Ensilage de maìs & 184 & - & 64 & - & $3,03^{*}$ & $\ldots$ & Maize silage & $I I$ \\
\hline \multirow[t]{3}{*}{ III } & Foin + pulpes & 72 & 111 & 23 & 32 & 1,04 & 1,45 & Hay + pulps & $I I I$ \\
\hline & & 1 & 2 & 1 & 2 & 1 & 2 & & \\
\hline & & \multicolumn{2}{|c|}{$m g N$} & \multicolumn{2}{|c|}{$m g N / l$ gas } & \multicolumn{2}{|c|}{$m g N / m V F A$} & & \\
\hline
\end{tabular}

(1) Sans luzerne déshydratée. Without dehydrated lucerne.

(2) Avec luzerne deshydratée $(3,5$ à $5,2 \mathrm{~g})$. With dehydrated lucerne $(3,5$ to $5,2 \mathrm{~g})$.

Dans les essais I, II et III, la nature (orge ou pulpe) et la quantité des substrats énergétiques ajoutés au milieu d'incubation ont été différentes.

In assays $I, I I$ and $I I I$, nature (barley or pulp) and quantity of energetic substrates added to the incubation medium were different.

* Valeurs estimées à partir de la production de gaz. Estimated values from gas production.

Dans l'essai I l'intervalle de confiance 5 p. 100 des valeurs données est 9,4 $\mathrm{mg} \mathrm{N}$ ou 3,8 $\mathrm{mg} \mathrm{N}$ par litre de gaz.

In assay I the confidence interval of 5 p. 100 of the given values is $9.4 \mathrm{mg} N$ or $3.8 \mathrm{mg} N$ per litre of gas.

\section{SUMMARY}

\section{IN VITRO STUDY OF PROTEOLYSIS \\ AND PROTEOSYNTHESIS IN THE RUMEN}

The amount of amino acids available in the ruminant intestine is dependent on the quantity of dietary proteins that escape from the break-down into ammonia (proteolysis) in the rumen and on the quantity of bacterial proteins synthetized (proteosynthesis) from ammonia. By using a simple incubation technique of rumen contents, we tried to determine the importance of the proteolysis and of the proteosynthesis as well as their variations from the changes in the ammonia content of the medium.

The technique used consisted in incubation in an Erlenmeyer (for 6 hours) of the nitrogenous source (about $0.25 \mathrm{~g}$ nitrogen) with high quantities of rumen contents $(200 \mathrm{~g})$ and of juice (200 $\mathrm{ml})$ taken $\mathrm{I}$ hour after the meal, $400 \mathrm{ml}$ of McDougall artificial saliva and an energetic source ( 3 to Io $\mathrm{g}$ barley or pulp according to the assays). Rumen content and juice came from fistulated cows accustomed to eat the tested diet and nitrogenous source. 


\title{
A. - Compared proteolysis of different protein sources
}

An important proteolysis (or ammoniogenesis) is characterized by a high ammonia concentration at the beginning of the fermentation (after I hour) and by a further slight decrease or even increase of that concentration. Those two criteria allowed us to classify the nitrogenous sources in a decreasing order of proteolysis magnitude (whatever the feed used) : peanut meal, soyabean oil-meal, dehydrated lucerne. The nitrogen proportion in the oil-meals converted into ammonia has been determined according to two methods :

I. by adding the ammonia used in the proteosynthesis to the ammonia apparently formed during incubation (for a given diet, we supposed that the proteosynthesis obtained with oilmeals was similar to that obtained with urea).

2. by comparing the kinetics of the amounts of ammonia obtained with the studied nitrogenous sources to those obtained with a control incubation without any supplementary nitrogenous source. The proportion of nitrogen in the oil-meals converted into ammonia during incubation was $2 \mathrm{I} .2 \pm \mathrm{I} .6$ and $4 \mathrm{I} .3 \pm 2.9$ p. Ioo respectively with soyabean and peanut oilmeal, by using the first method and $\mathrm{I} I .9 \pm \mathrm{I} .4$ and $32.0 \pm 2.8 \mathrm{p}$. roo by using the second one.

\section{B. -. Proteosynthesis from $N$-urea}

The hydrolysis of urea being immediate (the ammonia concentration maximum was observed $\mathbf{I} / 2$ hour after the beginning of incubation), the proteosynthesis can be determined by the quantity of nitrogen disappeared during incubation.

The magnitude of proteosynthesis depended on the feed used (isoenergetic feeds). The feeds have been classified according to the following decreasing order : $1^{0}$ maize silage, $2^{0}$ grass hay + pulps, $3^{\circ}$ grass hay + beets (assay $\mathrm{I}$, table $\mathrm{I}$ ). The decrease in proteosynthesis corresponded to a decrease in the fermentations (quantity of gas and volatile fatty acids formed) and also to a diminution of the quantity of bacterial nitrogen formed and expressed as related to the amount of volatile fatty acids.

With all diets studied dehydrated lucerne added to the fermentation medium had a stimulatory effect on proteosynthesis (table I).

This method has to be improved particularly in order to better take into account the ammoniogenesis from the contents themselves, but according to us, it seems to be an efficient technique for analysing the different factors that may affect proteolysis and proteosynthesis.

The quantities of bacterial nitrogen synthetized from mole of VFA ( 0.3 to $3 \mathrm{~g}$ ) were lower on an average than the value $\left(2.4\right.$ to $2.8 \mathrm{~g}$ ) observed in vitro $\left({ }^{35} \mathrm{~S}\right)$ by WALKER and NADER (1968) and in vivo by Hogan and Weston (r97o).

\section{VARIATIONS DE LA TENEUR EN ACIDES GRAS VOLATILS (AGV) DU SANG PÉRIPHÉRIQUe, CHEZ LE CHEVAL, EN FONCTION DU RÉGIME ALIMENTAIRE ET DE L'ACTIVITÉ MUSCULAIRE}

\author{
C. JEAN-BLAIN \\ Laboratoire de la Chaire d'alimentation, \\ École nationale vétérinaire, I. N.R. A., \\ 2, quai Chauveau, \\ 69337 Lyon Cedex 01
}

Ayant l'intention d'étudier l'utilisation métabolique des acides gras volatils issus de la diges; tion bactérienne des glucides, nous avons jugé utile, dans un travail préliminaire, d'examiner 